Georgia State University

ScholarWorks @ Georgia State University

$1-3-2012$

\title{
From Cities to Suburbs: Intrametropolitan Location and Growth of Ethnic Enterprises
}

Cathy Yang Liu

Georgia State University, cyliu@gsu.edu

Samir Abdullahi

Georgia State University

Follow this and additional works at: https://scholarworks.gsu.edu/uwrg_workingpapers

\section{Recommended Citation}

Liu, Cathy Yang and Abdullahi, Samir, "From Cities to Suburbs: Intrametropolitan Location and Growth of Ethnic Enterprises" (2012). UWRG Working Papers. 44.

https://scholarworks.gsu.edu/uwrg_workingpapers/44

This Article is brought to you for free and open access by the Usery Workplace Research Group at ScholarWorks @ Georgia State University. It has been accepted for inclusion in UWRG Working Papers by an authorized administrator of ScholarWorks @ Georgia State University. For more information, please contact scholarworks@gsu.edu. 
Working Paper 2012-1-3

January 2012

\section{From Cities to Suburbs:}

Intrametropolitan Location

and Growth of Ethnic

Enterprises

Cathy Yang Liu

Georgia State University

Samir Abdullahi

Georgia State University 


\title{
From Cities to Suburbs: Intrametropolitan Location and Growth of Ethnic Enterprises
}

\author{
January 2012 \\ Cathy Yang Liu ${ }^{1}$ \\ Georgia State University \\ Samir Abdullahi \\ Georgia State University
}

\begin{abstract}
This study traces the geographic evolution of minority-owned businesses in submetropolitan areas across the United States and investigates potential factors that underlie their intra-metropolitan location shift. Using data from the 2002 and 2007 Survey of Business Owner, this study addresses these questions for Asian-, Black- and Hispanic-owned enterprises in 19 selected large metropolitan areas in the U.S. It is found that ethnic enterprises have a stronger presence in the cities versus the suburbs but have experienced faster growth in the suburbs. The rate and direction of this spatial shift varies by ethnic business type, region, and metropolitan context.
\end{abstract}

Keywords: ethnic enterprises, spatial distribution, economic performance

\footnotetext{
${ }^{1}$ Direct correspondence to Department of Public Management and Policy, Andrew Young School of Policy Studies, Georgia State University, Atlanta, GA 30303, cyliu@gsu.edu .
} 


\section{INTRODUCTION}

Ethnic enterprises ${ }^{2}$ are an increasingly important growth segment in the U.S. urban economy. The Census Bureau's Survey of Business Owners (SBO) shows that the number of minority-owned businesses grew at twice the national average for all U.S. businesses from 2002 to 2007 (U.S. Small Business Administration, 2007). They not only contribute to the overall economic diversity and vitality of metropolitan areas, but also employ a large number of minority workers and play important roles in the economic life of minority and ethnic communities. Entrepreneurial entry is argued to provide an alternative route of upward mobility and economic advancement for ethnic workers. From Little Havana in Miami to Chinatown in New York, enclave economies where ethnic enterprises abound facilitate the economic assimilation and intergenerational mobility of the ethnic population, as well as contribute to local community development (Wilson and Portes, 1980; Zhou, 1992).

The recent growth of minority-owned enterprises has happened in a period that metropolitan areas undergo significant spatial, economic and demographic changes. These include the suburbanization of employment and economic activities (Hill and Brennan, 2005), and the residential redistribution of minority and immigrant populations in urban areas (Frey 2006; Singer, 2008). While there is a growing body of literature on ethnic enterprises, few have examined their geographic (re)distribution on the sub-metropolitan level, i.e., their evolving spatial pattern between central cities and the suburbs in a restructured urban economy. Ethnic enterprises might be highly tied to inner city areas to carve out their businesses operations as they rely on these communities for a protected market, workforce and consumer base, as well as financing and other needs (Aldrich and Waldinger, 1990; Zhou, 2004). But at the same time, like

\footnotetext{
${ }^{2}$ Ethnic enterprises are used interchangeably with minority owned businesses and refer to Asian-, Black-, and Hispanic-owned enterprises. According to Yinger (1985), ethnic entrepreneurs are business owners or self-employed workers whose group membership is tied to a common cultural background (Zhou and Cho, 2010).
} 
other employers, ethnic entrepreneurs should also be concerned with the business cost and market, labor pool and clientele access across different urban locations. They may thus be attracted to suburban locations where economy of scale is formed with the proximity to other businesses. They might follow the residential suburbanization of minority and immigrant populations as well (Frey 2006; Singer 2008). These perspectives offer possibly diverging predictions on the effect of residential mobility and metropolitan socioeconomic structure on the intrametropolitan location and performance of minority enterprises and warrant careful evaluation. A better understanding of the relative size and performance of ethnic enterprises in central city and suburban communities can inform policymakers and planners about the unique roles they can play in the local economy and design targeted policies that address their needs. Through identifying the potential factors that drive the spatial (re)location of these firms we can also predict their future growth and potential economic impact in various jurisdictions.

Thus, this study explicitly examines the intrametropolitan location and growth of ethnic enterprises, and their associated economic contribution in central city and suburban communities. To address these important questions, this study mainly makes use of two data sources: Survey of Business Owners 2002 and newly released 2007 data, and population data from corresponding years (Decennial census 2000 and American Community Survey 2005-7). The Survey of Business Owners makes available the number of Asian-, black- and Latino-owned firms, their sales and receipts (with and without paid employees), as well as number of paid employees and total payroll (for those with employees) on the county and place level. These statistics provide important information on the intensity and performance of minority enterprises. Census and American Community Survey data provide important supplementary information on the population characteristics of each county and place, which are essential for this study. 
Specifically, this research has the following objectives: 1 . To document the geographic distribution of Asian-, black- and Latino- owned businesses within these metropolitan areas. The center's share of a MSA's minority business presence and intensity, by number of businesses, total sales and receipts, number of employees, as well as total payroll, will be compared across the study years. It can be expected that minority businesses will suburbanize with the larger employment sectors as well as their respective minority populations, but the relative degrees of such decentralization is less clear; 2 . To compare the economic performance of ethnic enterprises located in cities and suburbs to see if there exist systematic differences among firms in different submetropolitan locations; 3 . To test hypotheses on how the relative centralization or suburbanization of minority businesses varies with region, intrametropolitan population shift, and immigrant size and growth.

\section{REVIEW OF LITERATURE AND RESEARCH HYPOTHESES}

While the importance and growth of ethnic enterprises have been well documented in recent literature, their intrametropolitan location pattern and relative performance in central cities and suburbs have not been systematically examined. Regional and metropolitan opportunity structure, local economic conditions, demographic dynamics, institutional capacity, policy environment and social milieu all interact to shape the course of business development and entrepreneurial activities (Armington and Acs, 2002; Lee, Florida and Acs, 2004; Hackler and Mayer, 2008; Wang 2010). On the metropolitan level, metropolitan structural and spatial factors, as exemplified by access to financial resources, market access (industry intensity), entrepreneurial skills integration and institutional support, play an important role in women-, Hispanic-, and black-owned businesses more than human capital related factors. Population 
diversity also has a stable effect on Hispanic business ownership across 50 MSAs (Hackler and Mayer, 2008). In addition, different types of immigrant gateways have distinctive impacts on ethnic entrepreneurship, which is also affected by the regional labor market (Wang, 2010).

Studies on the spatial pattern of ethnic enterprises on the intrametropolitan level usually take the form of individual case studies (e.g., Yoon 1991 on Chicago, Boston and Ross 1996 on Atlanta, Light 2002 on Los Angeles, and Fong, Chen, and Luk 2007 on Toronto) with few exceptions (Oh, 2007). Using census population data, Oh found that decline in intrametropolitan manufacturing employment (as an aspect of local economic restructuring), and growth in metropolitan-level immigrant population both give rise to central-city self-employment. At the same time, central city and suburban areas are interdependent and the economic transformations of both affect central city self-employment (2007). The use of population data, however, precludes the examination of business performance. Ethnic-owned firms' location decisions are shaped by the local economy, spatial location, and variation in neighborhoods (Rekers \& van Kempen, 2000). Additionally, factors like the reliance on ethnic networks and business sector participation have been shown to have a strong effect on these businesses (Zhou, 1998). In Atlanta, over half of black business owners identified reasons of being close to customers/clients, cost effectiveness, and being convenient and accessible for their present business locations (Boston and Ross, 1996). In terms of spatial pattern, Fong, Chen, and Luk found substantive Chinese business presence in suburban Toronto as compared to its central city (2007). They attribute Chinese businesses' locational pattern to four broad factors: ethnic characteristics in the neighborhood, size of business, industrial configuration in the area, and the presence of ethnic malls. Despite these studies, analysis of the general trends on ethnic enterprises' intrametropolitan spatial distribution is lacking. It is not clear whether central city locations 
remain an attractive business option for ethnic firms when both employment and population continue to suburbanize.

Evidence concerning the performance of ethnic businesses operating in different markets has shown that ethnic firms located within the ghettos or ethnic enclave tend to be small, undercapitalized, and more limited in growth opportunities than ethnic firms located outside (Bates, 1995, Ley, 2006). Bates and Robb (2008) found that the young neighborhood firms mainly serving minority clients and especially neighborhood minority market rather than broader regional marketplace are associated with lower business survival rate. In particular, business returns and performance in ethnic enclaves and central city protected markets are lower than those operating outside of enclaves or in the larger metropolitan area for both blacks (Cummings 1999) and Hispanics (Aguilera 2009). Such performance discrepancy is argued to be a result of the relatively smaller markets, less affluent consumers, higher insurance rates, limited access to credit and capital, as well as higher theft rates associated with inner city neighborhoods (Tabb, 1970). In addition, competition might be intense among ethnic firms selling similar goods and services within the enclave economy, and there might also be social and ethnic obligations that these firms need to accommodate (Aguilera, 2009). Thus, it can be expected that ethnic businesses located in central cities have lower levels of business performance than those located in suburban communities.

Several research hypotheses are derived with regards to metropolitan variation on ethnic enterprises' evolving spatial patterns. The intrametropolitan growth and performance of ethnic businesses is determined by the overall urban spatial, economic, social, and policy contexts, and it is hypothesized that it varies with region, residential shift, and size and growth of the immigrant population. Glaser and Kahn (2001) investigated employment decentralization and 
found that most American cities are currently decentralized. According to their study, the Midwest was the most decentralized by many measures, followed by the South. This trend may apply to ethnically owned business as well if their locational decision conforms to the same motivating factors as non-ethnic firms. This is upheld by another study which found that ethnic business location was influenced by access to market potential, the ability to use the ethnic group dominance in an industry to exploit others, as well as access to wealthier clienteles (Ram et al, 2002). It is a question whether these motivations will override ethnic businesses' historical reliance on central city neighborhoods to fill in the market niche deserted by mainstream business community (Light 1972, Aldrich et al 1985).

Of equal importance to ethnic firms are the ethnic communities from where they draw their protected market, stable consumer base, ethnic workers, and other resources (Aldrich and Waldinger 1990; Zhou 2004). While ethnic communities used to concentrate in inner city neighborhoods, recent years witnessed the emergence of ethnic communities of various socioeconomic status in both central city and suburban areas (Li, 1998; Logan, Alba, \& Zhang, 2002). These communities would necessarily feature different level of resource provision for aspirant ethnic entrepreneurs, especially when interacted with the larger metropolitan spatial and economic structures. As ethnic nodes with tight social linkages open up in the suburbs, it is likely that similar conditions for ethnically owned businesses to thrive in the central cities would exist in these areas as well. Though not all ethnic firms necessarily rely on ethnic markets, they will likely follow the settlement pattern of their respective population groups.

At the same time, the continued increase of the immigrant population, especially Asian and Latino immigrants, also contribute to the growth of ethnic businesses in major metropolitan areas (Bowles and Colton, 2007). Immigrants not only engage in entrepreneurial activities as 
owners, but also contribute to these businesses as workers, consumers, and developers. While immigrants continue to arrive in traditional "gateway" metropolitan areas, they have also begun to disperse from established gateways and settle directly to new destinations (Singer 2004;

Hempstead 2007). The relative recency of immigrant populations in an urban area matters as it is found that newer immigrant gateways and more established gateways have distinctive impacts on ethnic entrepreneurship (Wang, 2010). Given the fact that newer immigrant cohorts are more likely to settle in central city locations and the more established immigrants in suburbs, it can be expected that ethnic businesses in metropolitan areas with faster immigrant growth are suburbanized to a lesser extent. In sum, the intrametropolitan spatial (re)distribution of ethnic businesses would vary according to region, intrametropolitan population shift, and immigrant growth.

\section{DATA AND CONTEXT}

\section{Data and Sample}

The major data source used in this analysis is the 2002 and 2007 Survey of Business Owners (SBO). The SBO is an important component of the Economic Census which is collected every five years and is randomly distributed to over 2 million businesses throughout the United States based on previously filed IRS statements and other governmental and public sources of information $^{3}$. The SBO is one of the largest national business surveys that target small and large firms alike, while also requiring detailed demographic information on the firm owners. Businesses are categorized by geographical location, industrial classification, and business owner

\footnotetext{
${ }^{3}$ See http://www.census.gov/econ/sbo/methodology.html for more information on its methodology.
} 
demographics. Firm data on employment size, sales and receipts, and payroll statistics are also included as indicators of business performance. During the SBO sampling process, firm owners are asked to self-identify their racial group and those firms which non-Hispanic Whites do not have a controlling interest are classified as a minority owned firm. One area of concern is that firm owners in the SBO who declare themselves to have multi-racial proprietorship, either by a single individual or a collection of owners with varying racial identities, are classified into more than one racial category. Another problematic area is that firms counted in one geographic area are defined as the sum total of all establishments of that firm, even though all establishments may not fall within that partial geographic area. These issues aside, it provides comprehensive information on the location and business performance of minority-owned businesses. Population data, especially the size and growth of minority and immigrant populations are drawn from the 2000 Census and the 2005-2007 American Community Survey.

The scope of this research is limited to Metropolitan Statistical Area (MSA) and place level data with places being used as a proxy for central urbanized areas, or central cities. The SBO defines place as any municipality with a population of 2,500 and 5,000 for 2002 and 2007 respectively. For this study, the largest place by population within each MSA boundary is identified and used to capture the central city area of each metropolitan area. Suburban parts of an MSA are established by extracting the primary place level data from the MSA level data. This allows us to measure the degree of decentralization of minority owned firms by comparing the central city of an MSA to the suburban regions over time. We start with the top 100 largest MSAs in 2000 (by population) and their respective central cities. Using the 2002 and 2007 SBO, data for six categories (number of firms, sales and receipts for employee and non-employee firms, the number of paid employee firms, the number of paid employees, sales and receipts for 
employee firms, and annual payroll) for all ethnic business groups: Asian-owned, black-owned, and Hispanic-owned businesses were extracted. Out of the original list of 100 MSAs, only 19 MSAs have complete information for all firm indicators for both years on both the central city and MSA level. These 19 MSAs and their respective central cities and suburbs thus comprise the sample of this research. In addition, we also collected population data from the 2000 census and 2005-7 American Community Survey in order to test the afore-mentioned research hypotheses. National summary statistics were also included to use as benchmarks of national trends. A fourth business category was created and termed as "other" to capture all non-minority owned businesses by subtracting the Asian, Black, and Hispanic firm data from total firm data. The resulting sample and summary statistics are described below.

\section{Summary Statistics}

[Table 1 about here]

Table 1 shows the share of minority and non-minority owned firms and their corresponding growth rates from 2002 to 2007 for the 19 MSA sample. National statistics for the same groups are also presented to show comparability. When compared to national data, these 19 MSAs host around 28 percent of all firms and all employer firms in the United States for both years. The 19 MSA sample tends to over-represent minority owned firms. This is not surprising given that these MSAs are some of the most populous metropolitan areas and have traditionally had high concentrations of minority population. The percentage of minority-owned firms and minority-owned employer firms of all firms grew uniformly between 2002 and 2007, comprising greater share of the overall economy. In 2007, Asian-owned firms make up 5.7 percent of all firms in the U.S., with the numbers for Black-owned firm and Hispanic-owned firms being 7.1 
percent and 8.3 percent respectively. Asian-owned firms even have a greater share among all employer firms (6.9 percent) while the opposite is true for the other two groups.

The growth rates of minority owned firms are much stronger from 2002 to 2007 than non-minority firms. This holds true when looking at the 19 sample MSAs and the national statistics. Asian-, Black-, and Hispanic-owned firms have growth rates ranging from 20 to 50 percentage points higher than non-minority firms. Employer firms owned by minorities also had around 20 percentage point difference in growth rates as compared to non-minority firms. The stronger growth rates for minority firms require a note of caution given that these may be attributed to their lower starting points than non-minority firms. This point aside, the consistently superior growth trajectory for minority firms speaks to growing opportunities for minorities in establishing their own businesses. The central city and suburban number and growth of ethnic enterprises for each MSA is provided in Appendix A.

[Table 2 about here]

Table 2 looks at several business performance indicators by comparing the average of the sample MSAs used in this study to the national average. These include the sales $\&$ receipts and percentage employer firms for all firms, and sales \& receipts, number of employees and annual payroll for employer firms. Just as Table 1 indicates, the sample is reflective of similar trends occurring in minority and non-minority businesses when compared to the nation as a whole. Non-minority owned firms have significantly higher business performance levels in the sample average and national average. Excluding non-minorities, Asian owned firms had the largest sales and receipts for all firms and employer firms, followed by Hispanics and Blacks. This holds true for each level of geography. 
While the percentage of employer firms out of all firms decreased between 2002 and 2007 for all business groups, Asian firms manage to maintain a level (in the 25 percent range), similar to non-minority owned firms. Black owned businesses on the other hand dip to a share of slightly above 5 percent employer firms of all firms by 2007. Hispanic firms experienced very little change in that number during those years, hovering at 10 to 11 percent. This implies that the growth of non-employer firms outpaced that of employer firms for all groups over the five year period. As another example, the mean number of employees for non-minority owned employer firms (over 20 for both sample and national for both years) are more than twice that of the averages of minority owned employer firms (between 6 and 9 for all groups for both years). The other indicators, including sales and receipts and total payroll saw slight increases over the recent years for all business groups.

\section{FINDINGS}

\section{Intrametropolitan location and growth of ethnic businesses}

[Table 3 about here]

In order to understand the intrametropolitan location shift and relative economic impact of ethnic firms, we compare the share of Asian-owned, black-owned, and Hispanic-owned firms out of all firms as well as their associated sales and revenue, annual payroll, and employment in cities and suburbs respectively (Table 3). We find that minority owned firms have a stronger presence in the central city with a slightly higher share of all firms in the city as compared to the minority firms in the suburban areas for both 2002 and 2007. This holds true even when separating out employer firms alone. It is worth noting that both black-owned and Hispanic- 
owned firms are more under-represented among employer firms than they are among all firms, a fact that is also seen from Table 2. Despite their strong presence in the cities, minority-owned firm all have higher growth rates in the suburbs than in the cities between 2002-7 for all firms and employer firms. The largest growth disparity is found among Hispanic-owned firms (18.2 percent in the cities versus 40.2 percent in the suburbs). As ethnic enterprises continue to thrive in the suburbs, their economic impact is sure to become more prominent in these areas. At the same time, non-minority firms in our sample had contracted in growth in the cities from 2002 to 2007. Thus, much of the marginal growth in employer firms in cities can be attributed to minority firms and their role in the community development of these areas cannot be neglected.

Despite making major gains in the number of firms, performance indicators like sales and revenue were much less promising for minority owned firms as compared to non-minority firms. The share of total sales and revenue and total payroll in both central city and suburbs was extremely small for minority firms (around 2 percent for Asian-owned, around 1 percent for Hispanic-owned, and around 0.5 percent for Black-owned) varied little overtime. This suggests that even as the share of minority owned firms is increasing, their economic impact in the overall economy remains relatively small. Nevertheless, the growth rates for these indicators were significantly higher for minority owned firms most likely due to their low starting positions. In terms of total employment, all minority businesses combined hire about 7 percent of all central city work force and about 6.5 percent of all suburban workforce in 2007 (an increase from 5.2 percent in 2002). Given the fact that minority owned firms tend to hire more minority workers (Appold and Kasarda, 2004), their growth is sure to benefit the minority population. One interesting finding is that the employment of Hispanic-owned firms actually decreased in the central cities (negative 9.9 percent) while it increased in the suburbs (26.7 percent). It suggests 
the particularly strong growth of Hispanic-owned firms in the suburbs, a phenomenon goes in tandem with the fast suburbanization of the Hispanic population in recent years (Lichter et al, 2009).

\title{
Ethnic firms and business performance in cities and suburbs
}

\author{
[Table 4 about here]
}

In an effort to understand the relative business performance of a typical minority-owned firm in city versus suburbs and change over time, we further compare the same performance metrics against their non-minority counterparts for the same 19 MSAs (Table 4). In general, we find that minority owned businesses in the suburbs have stronger performance measures than their counterparts in the city across most indicators for each year examined (the only exception being number of employees for Hispanic-owned and black-owned firms in 2002), while the reverse is true for non-minority firms with firms in the cities outperforming those in the suburbs. However, these spatial disparities are not large in most cases. Between 2002 and 2007, all minority employer firms grew in scale in the suburban areas, as demonstrated by higher total sales and receipts, number of employees, and annual payroll, but shrank or stagnated in terms of employment and payroll in the cities. At the same time, the share of employer firms out of all firms decreased in both subareas for all minority firm groups. It suggests that the growth of nonemployer firms outpaced that of employer firms. While a typical minority firms lags behind a typical non-minority firm in the same location along all dimensions, Asian-owned firms on average feature the highest total sales and receipts and percentage employer firms, as well as sales and receipts for employer firms in the cities. Hispanic-owned employer firms on average hire the most workers among all minority firms (9.5 and 7.9 for cities and suburbs in 2002, and 7.2 and 7.9 respectively in 2007) and have the highest annual payroll. They also have the highest 
average sales and receipts in the suburbs. These dynamics demonstrate the fact that the business performance of Hispanic-owned firms with paid employees are at least on par with that of Asianowned firms though their nonemployer counterparts tend to underperform.

[Table 5 about here]

We further track central city's share of metropolitan area firms and their overall economic impact from 2002 to 2007 for each business type. The weakening of central city location in the overall spatial distribution of firms across metropolitan areas is quite consistent. Of all the firms, black-owned firms are the most centralized, with slightly over half of all their firms, employer firms, sales and receipts, employment, and annual payroll occurring within the city limits. This business group however also witnessed the most drastic decentralization trend between 2002 and 2007 as measured by percentage points. The non-minority firms are the least centralized, but the decentralization of their firms and economic benefits has been the smallest as well. Asian- and Hispanic-owned firms are similar in their level of centralization, with almost 44 percent of firms located in central cities in 2002 and less than 42 percent in 2007. If these trends continue into the future, we can expect to see ethnic enterprises become more suburbanized in the coming years and the economic benefits they bring will increasingly accrue to suburban locations as well.

\section{Testing hypotheses on ethnic businesses' locational distribution}

In a final set of analysis, we further test three hypotheses on the metropolitan variation of ethnic business (de)centralization. It is hypothesized that the relative intrametropolitan spatial pattern of ethnic businesses varies by region, intrametropolitan population shift, as well as the 
size and growth of the metropolitan immigrant population. These hypotheses are tested using descriptive statistics instead of regression analysis due to the small sample size.

[Table 6 about here]

Table 6 reveals regional differences in the spatial distribution of various business types. While Glaser and Kahn (2001) found the Midwest to be the most decentralized for total employment followed by the South, this pattern does not apply to all business types. Asianowned, Hispanic-owned firms as well as non-minority firms in the Midwest have the lowest shares of their businesses located in the central cities in both years (13.4 percent, 31.8 percent, and 9.5 percent respectively). The South also comes second in the level of decentralization. This is not true for black-owned businesses however, which are most centralized in Midwestern metropolitan areas (64.7 percent of MSA businesses located in the central cities). The Northeast is the region which has the large shares of all businesses located in the central cities: 60 percent for Asian-owned firms, 64.6 percent for black-owned firms, 56.8 percent for Hispanic-owned firms, and 31.9 percent for non-minority firms. In the majority of cases, central city share of businesses shrank between 2002 and 2007 suggesting a general decentralization trend, but there are several exceptions. The spatial patterns of employer only firms are varied by business type and region as well.

Ethnic communities can provide the resources, labor pool, and market for ethnic entrepreneurs. As the "protected market hypothesis" implies, ethnic entrepreneurs find their niches in ethnic communities given their particular understanding of the preference and consumption behavior of coethnics, and special ties with homeland for ethnic goods (Light, 1972). Ethnically concentrated communities also provide ethnic entrepreneurs with a stable 
consumer base for ethnic goods, recruitment channels for ethnic suppliers and workers, easy access to credit and capital and social networks in business startup (Aldrich \& Waldinger, 1990; Zhou, 2004). Given the important business incubation role played by ethnic communities, it can be expected that the spatial shift of ethnic businesses is parallel to the spatial shift of their respective ethnic populations.

[Figure 1 about here]

Figure 1 plots the percentage change in relative centralization of MSA businesses against the percentage change in relative centralization of MSA population for the 19 MSAs in the period 2002 to 2007 (detailed data for each MSA are provided in Appendix B) . The X-axis represents the change in the central cities' share of population, and the Y-axis is the change in the central cities' share of businesses. These four graphs show the scatterplots for Asian population and businesses, black population and businesses, Hispanic population and businesses, as well as total population and businesses respectively. The diagonal dashed line dividing each graph represents the null hypothesis, that there is no difference between the rate and direction of change in the concentration of ethnic firms and ethnic population in the central cities. While the plots for Asian, Hispanic, and total firms show a very similar trend, black businesses depict a somewhat different pattern. The overarching trend is that businesses are suburbanizing at a greater rate than their respective population or suburbanizing despite a centralizing population in the majority of metropolitan areas. This is illustrated by the fact that most MSA dots lie below the $\mathrm{X}$-axis and also below the diagonal line. There only exist a few exceptions: Albuquerque NM, New York, NY, Springfield MA, and Boston, MA. In the case of black-owned firms however, 9 MSA dots lie above the diagonal line, suggesting that they either suburbanize at a 
slower rate than the population, or have become more centralized despite a decentralizing population (4 MSAs).

The rise of suburban diversity with growing black, Hispanic, and Asian populations has been well documented (Frey, 2001; Logan et al 2002; Frey et al 2009). In light of this context, the lag-behind of black businesses towards the suburbs is worth-noting. While the current analysis does not offer any definite answers to this phenomenon, there can be several potential explanations. First of all, black-owned businesses might have special ties to central city communities that are rooted in history and the existing policy framework. For example, government programs that promote minority business development including preferential procurements and set-asides are more likely to exist in central cities, especially cities with black mayors (Bates 1997). Second, there could be access barriers for black entrepreneurs that are stronger in the suburbs than in the cities. Last, close-knit business community of an enclave economy might not have developed in the black suburban community which hinders the business startup process.

[Table 7 about here]

The continued increase of immigrant population, especially Asian and Latino immigrants, contribute to the growth of ethnic businesses in major metropolitan areas (Bowles and Colton, 2007; Wang, 2010). Numerous typologies have been developed to characterize the phenomenon that immigrants have been increasingly settling away from established getaways and towards new destinations (e.g. Singer, 2004; Painter and Yu, 2010). Two criteria have usually been adopted in these typologies: the relative size of the immigrant population and the percentage of new immigrants (or recent growth). We use the same two criteria to categorize the 19 MSAs into 
four groups: high presence and high growth (group 1), low presence and low growth (group 2), high presence and low growth (group 3) and low presence and high growth (group 4). The cutoff thresholds were set to be 10 percent immigrant of total population in year 2000 for immigrant presence and 30 percent immigrant growth rate between 2000 and 2007 for immigrant growth. A detailed listing of these categories is presented in Appendix C. The most centrally concentrated Asian-owned, Hispanic-owned businesses are found in low-immigrant-presence and highimmigrant-growth MSAs. While the SBO data does not specify the nativity status of Asian and Hispanic business owners, it can be expected that the majority of them are immigrants. New immigrants might still find central city locations attractive for both residence and business, which help fuel the local economy of these neighborhoods (Hum, 2003; Bowls and Colton, 2007). These businesses are most suburbanized in low immigrant presence and low immigrant growth metropolitan areas. While being the most centralized of all businesses, black-owned firms are least centralized in high-immigrant-presence and high-immigrant growth MSAs. How a rising immigrant population in urban America is shaping the ethnic business scene across different types of metropolitan areas requires further examination. What is also interesting is how this surge is affecting the black-owned businesses that already exist in these areas and how coexistence and competition together define their interactions.

\section{CONCLUSION AND DISCUSSION}

Utilizing the recently released 2007 SBO data, this research tracks the intrametropolitan location, growth, and performance of ethnic enterprises and tests how ethnic business centralization (or suburbanization) varies with region, population shift and immigrant gateway type. While the suburbanization of metropolitan jobs and racial/ethnic minority populations have 
been well documented, the evolving spatial pattern of minority-owned businesses within metropolitan areas remains largely unknown. Results of this research can help understand the spatial dynamics and growth paths of the ethnic enterprises, thus informing policy makers and urban planners of the geographic distribution of minority business needs and economic impact within metropolitan regions. While the metropolitan area can be perceived as an integrated economic entity, the fact that most economic development programs and policies remain placebased and jurisdiction-based means that resources need to be utilized effectively. At the same time, the benefits that accrue from ethnic enterprises also apply more directly to its closer proximity.

The years between 2002 and 2007 witnessed the strong growth of ethnic enterprises in the United States. Despite this strong growth, their business scale remains relatively small, with the nonemployer firms dominating the growth. Even among the employer firms, the average number of employees per firm is less than 10. At the same time, the overall economic impact of minority owned businesses remain relatively low. Asian-owned, black-owned, and Hispanicowned businesses altogether make up less than 5 percent of the total sales and receipts as well as annual payroll in the 19 metropolitan areas, though the share of ethnic businesses among all businesses is much larger. The economic indicator that has a slightly larger impact is employment. Ethnic businesses together employ 7 percent of all workers in the central city and 6.5 percent of all workers in the suburbs. Given the fact that minority businesses do hire more minorities, especially in minority neighborhoods (Boston and Ross, 1996; Appold and Kasarda 2004), it can be expected that they play an important role in hiring minority workers. From a planning standpoint, policies need to be in place not just to facilitate entrepreneurial entry, but to follow through ethnic businesses' startup process to ensure ultimate future success. Numerous 
studies have identified the access barriers as well as financial constraints of ethnic firms (Bates 1997; Blanchard, Zhao and Yinger 2008; Servon et al 2010). The ultimate economic impact of these firms needs to be considered in addition to their growth in number in evaluating any existing and future policies that aim at promoting ethnic entrepreneurship.

In terms of spatial distribution, ethnic enterprises have a stronger presence in the cities versus the suburbs but have experienced faster growth in the suburbs between 2002 and 2007 . This is especially true for Asian-owned and Hispanic-owned firms, whose geographic shift seems to coincide with the residential suburbanization of their respective population. The rate and direction of this shift varies with region and metropolitan context. Metropolitan areas with low initial immigrant presence and high immigrant growth in the recent decade have the most centralized Asian- and Hispanic-owned businesses, possibly fueled by the newly arrived immigrants. Black-owned businesses, on the other hand, remain the least suburbanized of all groups and do not keep up the suburbanizing pace of the black population. It is possible that central cities provide favorable economic, social, and policy environment for black businesses while there exist higher entry barriers in the suburban market. Our results show that suburban ethnic firms all generally perform better than their central city counterparts, a finding consistent with earlier accounts on black-owned businesses alone (Cumming 1999). This raised the question of how to better utilize resources and effectively facilitate the growth of ethnic firms. Cummings concludes the limited validity of strictly place-based development strategies that might constrain the sphere of minority businesses and calls for broader policies that integrate minority firms into the mainstream economy. While this broader approach has its appeal, it is worth noting that minority business owners might choose otherwise. 
The changing intrametrpolitan location and growth of ethnic enterprises and their associated economic impact is sure to affect both the communities who gain on those businesses and those who lose. Ethnic businesses accrue economic and social benefits to the communities by hiring minority workers, generating tax revenue, serving unmet market needs, revitalizing commercial development, and promoting community life and diversity (Zhou 2004; Bates 2006; Bowles and Colton 2007). As ethnic enterprises continue to suburbanize, it might create spatial discrepancies between support services and business needs, as well as business services and market needs. While most existing small business services and programs serving minority firms might exist in the central cities, it is the suburbs that will experience the greatest growth in ethnic enterprises, especially Asian and Latino owned businesses. This discrepancy calls for careful assessment of business needs in the suburbs. At the same time, as many of these firms shift out of central city locations, what would it mean to the employment, tax base, market needs and locality development in their communities is also worth examination. Understanding these potential discrepancies can let planners better predict the future growth trajectories of ethnic enterprises within metropolitan areas and prepare for their possible community impact on both ends. As the U.S. society becomes increasingly diverse, successfully integrating ethnic enterprises in both the larger economy and local economic planning can further tap their potential into the future. 


\section{REFERENCES}

Aguilera, M. B. (2009). Ethnic enclaves and the earnings of self-employed Latinos. Small Business Economics, 33(4), 413-425.

Aldrich, H., Cater, J., Jones, T., Mc Evoy, D., \& Velleman, P. (1985). Ethnic residential concentration and the protected market hypothesis. Social Forces, 63(4), 996-1009.

Aldrich, H., \& Waldinger, R. (1990). Ethnicity and entrepreneurship. Annual Review of Sociology, 16(1), 111-135.

Appold, S. \& Kasarda, J. (2004). Building community through entrepreneurship: Lessons from Vietnam and the United States. In J. S. Butler \& G. Kozmetsky (Eds.), Immigrant and minority entrepreneurship, The continuous rebirth of American communities (pp. 61-84). Westport, Connecticut: Praeger Publishers.

Armington, C., \& Acs, Z. J. (2002). The determinants of regional variation in new firm formation. Regional Studies, 36(1), 33-45.

Bates, T. (1995). Self-employment entry across industry groups. Journal of Business Venturing, 10(2), 143-156.

Bates, T. (1997). Race, self-employment, and upward mobility: An elusive American dream. Johns Hopkins University Press.

Bates, T. (2006). The urban development potential of black-owned businesses. Journal of the American Planning Association, 72(2), 227-237.

Bates, T., \& Robb, A. (2008). Analysis of young neighborhood firms serving urban minority clients. Journal of Economics and Business, 60(1-2), 139-148.

Blanchard, L., Zhao, B., \& Yinger, J. (2008). Do lenders discriminate against minority and woman entrepreneurs? Journal of Urban Economics, 63(2), 467-497.

Boston, T., \& Ross, C. (1996). Location preferences of successful African American-owned businesses in Atlanta. The Review of Black Political Economy, 24(2), 337-357.

Bowles, J., \& Colton, T. (2007). A world of opportunity (pp. 1-60). New York: Center for an Urban Future.

Cummings, S. (1999). African American entrepreneurship in the suburbs - Protected markets and enclave business development. Journal of the American Planning Association, 65(1), 50-61.

Fong, E., Chen, W., \& Luk, C. (2007). A comparison of ethnic businesses in suburbs and city. City \& Community, 6(2), 119-136. 
Frey, W. H., A. Berube, A. Singer, and J. H. Wilson. (2009). Getting current: Recent demographic trends in metropolitan America. Washington, D.C.: The Brookings Institution Metropolitan Policy Program.

Frey, W. H., Urban, B. I. C. o., \& Policy, M. (2001). Melting pot suburbs: A census 2000 study of suburban diversity. Washington, D.C.: Brookings Institution Center on Urban and Metropolitan Policy.

Frey, William H. (2006). Diversity spreads out: Metropolitan shifts in Hispanic, Asian, and Black populations since 2000. Washington, DC: Brookings Institution Metropolitan Policy Program

Glaeser, E., Kahn, M., Arnott, R., \& Mayer, C. (2001). Decentralized employment and the transformation of the American city. Brookings-Wharton Papers on Urban Affairs, 1-63.

Hackler, D., \& Mayer, H. (2008). Diversity, entrepreneurship, and the urban environment. Journal of Urban Affairs, 30(3), 273-307.

Hempstead, K. 2007. Mobility of the foreign-born population in the United States, 1995-2000: The role of gateway states, International Migration Review, 22(4): 333-349.

Hill, E. W., \& Brennan, J. (2005). America's central cities and the location of work: Can cities compete with their suburbs? Journal of the American Planning Association, 71(4), 411-432.

Hum, T. (2003). Mapping global production in New York City's garment industry: the role of

Lee, S. Y., Florida, R., \& Acs, Z. (2004). Creativity and entrepreneurship: a regional analysis of new firm formation. Regional Studies, 38(8), 879-891.

Ley, D. (2006). Explaining variations in business performance among immigrant entrepreneurs in Canada. Journal of Ethnic and Migration Studies, 32(5), 743-764.

Li, W. (1998). Anatomy of a new ethnic settlement: The Chinese ethnoburb in Los Angeles. Urban Studies, 35(3), 479.

Lichter, D. T., \& Johnson, K. M. (2009). Immigrant gateways and Hispanic migration to new Destinations. International Migration Review, 43(3), 496-518.

Lichter, D. T., D. Parisi, M. C. Taquino, and S. M. Grice. (2009). Residential segregation in new Hispanic destinations: Cities, suburbs, and rural communities compared. Social Science Research 39: 215 - 230.

Light, I. (2002) Immigrant place entrepreneurs in Los Angeles, 1970-1990. International Journal of Urban and Regional Research 26, 215-228.

Light, I. H. (1972). Ethnic enterprise in America, business and welfare among Chinese, Japanese, and blacks. University of California Press. 
Logan, J., Zhang, W., \& Alba, R. (2002). Immigrant enclaves and ethnic communities in New York and Los Angeles. American Sociological Review, 67(2), 299-322.

Oh, J. H. (2008). The quest to understand self-employment in American metropolitan areas. Urban Studies, 45(9), 1769-1790.

Painter, G., \& Yu, Z. (2010). Immigrants and housing markets in mid-size metropolitan areas. International Migration Review, 44(2), 442-476.

Ram, M., Jones, T., Abbas, T., \& Sanghera, B. (2002). Ethnic minority enterprise in its urban context: South Asian restaurants in Birmingham. International Journal of Urban and Regional Research, 26(1), 24-40.

Rekers, A., \& Van Kempen, R. (2000). Location matters: Ethnic entrepreneurs and the spatial context. In J. Rath (ed.), Immigrant businesses: The economic, political and social environment (pp54-69). Londres: Macmillan Press.

Servon, L. J., Fairlie, R. W., Rastello, B., \& Seely, A. (2010). The five gaps facing small and microbusiness owners: Evidence from New York City. Economic Development Quarterly, 24(2), 126-142.

Singer, A. (2004). The Rise of New Immigrant Gateways. Washington, D.C.: The Brookings Institution Center on Urban and Metropolitan Policy.

Singer, A. (2008). Twenty-first-century gateways: Immigrant incorporation in suburban America. Washington, D.C.: Brookings Institution Press

Hum, T. (2003). Mapping global production in New York City's garment industry: The role of Sunset Park, Brooklyn's immigrant economy. Economic Development Quarterly, 17(3), 294-309.

Tabb, W. (1970) The political economy of the black ghetto. New York: W.W. Norton \& Company, Inc.

Wang, Q. (2010). Immigration and ethnic entrepreneurship: A comparative study in the United States. Growth and Change, 41(3), 430-458.

Wilson, K., \& Portes, A. (1980). Immigrant enclaves: An analysis of the labor market experiences of Cubans in Miami. American Journal of Sociology, 86(2), 295-319.

Yinger, M. J. (1985). Ethnicity. Annual Review of Sociology 11, 151-180.

Yoon, I. (1991). The changing significance of ethnic and class resources in immigrant businesses: The case of Korean immigrant businesses in Chicago. International Migration Review, 25(2), 303-332.

Zhou, M. (1992). Chinatown: The socioeconomic potential of an urban enclave: Temple University Press. 
Zhou, M. (2004). Revisiting Ethnic Entrepreneurship: Convergencies, Controversies, and Conceptual Advancements. The International Migration Review, 38(3), 1040-1074.

Zhou, M. and Cho M. (2010). Noneconomic effects of ethnic entrepreneurship: Evidence from Chinatown and Koreatown in Los Angeles, USA. Thunderbird International Business Review, 52(2), 83-96.

Zhou, Y. (1998). Beyond ethnic enclaves: Location strategies of Chinese producer service firms in Los Angeles. Economic Geography, 74(3), 228-251.

[Appendices are available upon request] 
Table 1. Number of Firms, Share and Growth by Owner's Race/Ethnicity, 2002, 2007, for Sample and U.S.

\begin{tabular}{|c|c|c|c|c|c|c|c|c|c|c|}
\hline \multirow[b]{3}{*}{19 MSA sample } & \multicolumn{2}{|c|}{ Asian-owned } & \multicolumn{2}{|c|}{ Black-owned } & \multicolumn{2}{|c|}{$\begin{array}{c}\text { Hispanic-owned } \\
\text { All Firms }\end{array}$} & \multicolumn{2}{|c|}{ Other } & \multicolumn{2}{|c|}{ All } \\
\hline & \multicolumn{10}{|c|}{2002} \\
\hline & 558957 & $8.8 \%$ & 419648 & $6.6 \%$ & 624337 & $9.9 \%$ & 4722381 & $74.7 \%$ & 6325323 & $100 \%$ \\
\hline \multirow[t]{2}{*}{ United States } & 1103587 & $4.8 \%$ & 1197567 & $5.2 \%$ & 1573464 & $6.8 \%$ & 19100037 & $83.1 \%$ & 22974655 & $100 \%$ \\
\hline & \multicolumn{10}{|c|}{2007} \\
\hline 19 MSA sample & 774868 & $10.3 \%$ & 680221 & $9.0 \%$ & 812582 & $10.8 \%$ & 5259792 & $69.9 \%$ & 7527463 & $100 \%$ \\
\hline \multirow[t]{2}{*}{ United States } & 1549559 & $5.7 \%$ & 1921864 & $7.1 \%$ & 2260269 & $8.3 \%$ & 21361216 & $78.8 \%$ & 27092908 & $100 \%$ \\
\hline & \multicolumn{10}{|c|}{ 2002-7 growth } \\
\hline 19 MSA sample & $38.6 \%$ & & $62.1 \%$ & & $30.2 \%$ & & $11.4 \%$ & & $19.0 \%$ & \\
\hline \multirow[t]{3}{*}{ United States } & $40.4 \%$ & & $60.5 \%$ & & $43.6 \%$ & & $11.8 \%$ & & $17.9 \%$ & \\
\hline & \multicolumn{10}{|c|}{ Employer Firms } \\
\hline & \multicolumn{10}{|c|}{2002} \\
\hline 19 MSA sample & 150452 & $9.8 \%$ & 31196 & $2.0 \%$ & 66528 & $4.3 \%$ & 1288780 & $83.9 \%$ & 1536956 & $100 \%$ \\
\hline \multirow[t]{2}{*}{ United States } & 319468 & $5.8 \%$ & 94518 & $1.7 \%$ & 199542 & $3.6 \%$ & 4911256 & $88.9 \%$ & 5524784 & $100 \%$ \\
\hline & \multicolumn{10}{|c|}{2007} \\
\hline 19 MSA sample & 186449 & $11.6 \%$ & 37880 & $2.3 \%$ & 82111 & $5.1 \%$ & 1306404 & $81.0 \%$ & 1612844 & $100 \%$ \\
\hline \multirow[t]{2}{*}{ United States } & 397426 & $6.9 \%$ & 106566 & $1.9 \%$ & 248852 & $4.3 \%$ & 4982718 & $86.9 \%$ & 5735562 & $100 \%$ \\
\hline & \multicolumn{10}{|c|}{ 2002-7 growth } \\
\hline 19 MSA sample & $23.9 \%$ & & $21.4 \%$ & & $23.4 \%$ & & $1.4 \%$ & & $4.9 \%$ & \\
\hline United States & $24.4 \%$ & & $12.7 \%$ & & $24.7 \%$ & & $1.5 \%$ & & $3.8 \%$ & \\
\hline
\end{tabular}

Source: Authors' calculation of Survey of Business Owner data. 
Table 2. Business Performance for Sample MSAs and U.S. by Owner's Race/Ethnicity, 2002-7

\begin{tabular}{|c|c|c|c|c|c|}
\hline & \multicolumn{2}{|c|}{ All Firms } & \multicolumn{3}{|c|}{ Employer Firms } \\
\hline & $\begin{array}{r}\text { Sales \& } \\
\text { Receipts } \\
\text { (in 1000\$) } \\
\end{array}$ & $\begin{array}{c}\text { \% Employer } \\
\text { Firms }\end{array}$ & 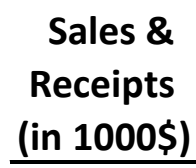 & $\begin{array}{l}\text { Number of } \\
\text { Employees }\end{array}$ & $\begin{array}{r}\text { Annual } \\
\text { Payroll } \\
\text { (in 1000\$) }\end{array}$ \\
\hline & \multicolumn{5}{|c|}{ Asian-owned 2002} \\
\hline Sample Average & 298.4 & $26.92 \%$ & 984.1 & 6.5 & 174.6 \\
\hline \multirow[t]{2}{*}{ National Average } & 296.0 & $28.95 \%$ & 911.4 & 6.9 & 175.4 \\
\hline & \multicolumn{5}{|c|}{ Asian-owned 2007} \\
\hline Sample Average & 338.9 & $24.06 \%$ & 1267.4 & 6.7 & 208.1 \\
\hline \multirow[t]{2}{*}{ National Average } & 326.6 & $25.65 \%$ & 1141.3 & 7.1 & 199.4 \\
\hline & \multicolumn{5}{|c|}{ Black-owned 2002} \\
\hline Sample Average & 73.4 & $7.43 \%$ & 716.8 & 7.5 & 192.9 \\
\hline \multirow[t]{2}{*}{ National Average } & 74.0 & $7.89 \%$ & 696.2 & 8.0 & 185.7 \\
\hline & \multicolumn{5}{|c|}{ Black-owned 2007} \\
\hline Sample Average & 74.5 & $5.57 \%$ & 966.1 & 7.5 & 198.8 \\
\hline \multirow[t]{2}{*}{ National Average } & 70.6 & $5.54 \%$ & 911.6 & 8.5 & 219.0 \\
\hline & \multicolumn{5}{|c|}{ Hispanic-owned 2002} \\
\hline Sample Average & 129.9 & $10.66 \%$ & 967.1 & 8.5 & 207.2 \\
\hline \multirow[t]{2}{*}{ National Average } & 141.0 & $12.68 \%$ & 899.6 & 7.7 & 184.0 \\
\hline & \multicolumn{5}{|c|}{ Hispanic-owned 2007} \\
\hline Sample Average & 141.4 & $10.10 \%$ & 1096.6 & 7.7 & 225.9 \\
\hline \multirow[t]{2}{*}{ National Average } & 155.1 & $11.01 \%$ & 1124.8 & 7.7 & 218.2 \\
\hline & \multicolumn{5}{|c|}{ Other 2002} \\
\hline Sample Average & 1431.2 & $27.29 \%$ & 5091.2 & 22.6 & 932.4 \\
\hline \multirow[t]{2}{*}{ National Average } & 1150.1 & $25.71 \%$ & 4336.9 & 21.6 & 753.8 \\
\hline & \multicolumn{5}{|c|}{ Other 2007} \\
\hline Sample Average & 1677.6 & $24.84 \%$ & 6576.5 & 23.1 & 1153.9 \\
\hline National Average & 1359.4 & $23.33 \%$ & 5665.2 & 22.4 & 936.4 \\
\hline
\end{tabular}

Source: Authors' calculation of Survey of Business Owners data. 
Table 3. Firm and Business Performance Composition and Growth by Owner's Race/Ethnicity for Cities and Suburbs, 2002-7

\begin{tabular}{|c|c|c|c|c|c|c|}
\hline & & Asian-owned & Black-owned & $\begin{array}{l}\text { Hispanic-owned } \\
\text { A/l Firms }\end{array}$ & Other & All \\
\hline \multirow{2}{*}{2002} & City & $10.4 \%$ & $9.9 \%$ & $13.6 \%$ & $66.1 \%$ & $100 \%$ \\
\hline & Suburbs & $8.1 \%$ & $5.0 \%$ & $8.0 \%$ & $78.9 \%$ & $100 \%$ \\
\hline \multirow{2}{*}{2007} & City & $12.0 \%$ & $12.8 \%$ & $13.5 \%$ & $61.7 \%$ & $100 \%$ \\
\hline & Suburbs & $9.4 \%$ & $7.2 \%$ & $9.5 \%$ & $73.9 \%$ & $100 \%$ \\
\hline \multirow{3}{*}{ Growth } & City & $37.4 \%$ & $52.7 \%$ & $18.2 \%$ & $10.8 \%$ & $18.7 \%$ \\
\hline & Suburbs & $39.4 \%$ & $71.4 \%$ & $40.2 \%$ & $11.6 \%$ & $19.1 \%$ \\
\hline & & \multicolumn{5}{|c|}{ Employer Firms } \\
\hline \multirow{2}{*}{2002} & City & $11.2 \%$ & $2.8 \%$ & $5.1 \%$ & $80.9 \%$ & $100 \%$ \\
\hline & Suburbs & $9.1 \%$ & $1.6 \%$ & $3.9 \%$ & $85.4 \%$ & $100 \%$ \\
\hline \multirow{2}{*}{2007} & City & $13.2 \%$ & $3.3 \%$ & $5.8 \%$ & $77.7 \%$ & $100 \%$ \\
\hline & Suburbs & $10.7 \%$ & $1.9 \%$ & $4.7 \%$ & $82.7 \%$ & $100 \%$ \\
\hline \multirow{3}{*}{ Growth } & City & $22.5 \%$ & $21.4 \%$ & $18.8 \%$ & $-0.2 \%$ & $3.9 \%$ \\
\hline & Suburbs & $24.8 \%$ & $21.5 \%$ & $26.5 \%$ & $2.1 \%$ & $5.5 \%$ \\
\hline & & \multicolumn{5}{|c|}{ Sales \& Revenue (All Firms) } \\
\hline \multirow{2}{*}{2002} & City & $2.2 \%$ & $0.5 \%$ & $1.1 \%$ & $96.1 \%$ & $100 \%$ \\
\hline & Suburbs & $2.4 \%$ & $0.4 \%$ & $1.2 \%$ & $96.0 \%$ & $100 \%$ \\
\hline \multirow{2}{*}{2007} & City & $2.8 \%$ & $0.6 \%$ & $1.2 \%$ & $95.3 \%$ & $100 \%$ \\
\hline & Suburbs & $2.9 \%$ & $0.5 \%$ & $1.2 \%$ & $95.4 \%$ & $100 \%$ \\
\hline \multirow{3}{*}{ Growth } & City & $64.0 \%$ & $52.5 \%$ & $48.8 \%$ & $29.7 \%$ & $30.8 \%$ \\
\hline & Suburbs & $54.1 \%$ & $74.7 \%$ & $37.9 \%$ & $31.1 \%$ & $31.9 \%$ \\
\hline & & \multicolumn{5}{|c|}{ Annual Payroll (Employer Firms) } \\
\hline \multirow{2}{*}{2002} & City & $1.9 \%$ & $0.6 \%$ & $1.1 \%$ & $96.4 \%$ & $100 \%$ \\
\hline & Suburbs & $2.2 \%$ & $0.4 \%$ & $1.1 \%$ & $96.2 \%$ & $100 \%$ \\
\hline \multirow{2}{*}{2007} & City & $2.1 \%$ & $0.6 \%$ & $1.1 \%$ & $96.3 \%$ & $100 \%$ \\
\hline & Suburbs & $2.7 \%$ & $0.4 \%$ & $1.3 \%$ & $95.6 \%$ & $100 \%$ \\
\hline \multirow{3}{*}{ Growth } & City & $37.6 \%$ & $23.9 \%$ & $23.9 \%$ & $27.5 \%$ & $27.6 \%$ \\
\hline & Suburbs & $53.5 \%$ & $26.3 \%$ & $41.5 \%$ & $24.1 \%$ & $24.9 \%$ \\
\hline & & \multicolumn{5}{|c|}{ Employment (Employer Firms) } \\
\hline \multirow{2}{*}{2002} & City & $3.4 \%$ & $1.0 \%$ & $2.3 \%$ & $93.3 \%$ & $100 \%$ \\
\hline & Suburbs & $3.0 \%$ & $0.6 \%$ & $1.6 \%$ & $94.8 \%$ & $100 \%$ \\
\hline \multirow{2}{*}{2007} & City & $3.8 \%$ & $1.1 \%$ & $2.0 \%$ & $93.1 \%$ & $100 \%$ \\
\hline & Suburbs & $3.9 \%$ & $0.7 \%$ & $1.9 \%$ & $93.5 \%$ & $100 \%$ \\
\hline \multirow{2}{*}{ Growth } & City & $14.8 \%$ & $10.3 \%$ & $-9.9 \%$ & $2.2 \%$ & $2.4 \%$ \\
\hline & Suburbs & $35.2 \%$ & $31.2 \%$ & $26.7 \%$ & $4.4 \%$ & $5.8 \%$ \\
\hline
\end{tabular}

Source: Authors' calculation of Survey of Business Owners data. 
Table 4. Business Performance by Owner's Race/Ethnicity in Cities and in Suburbs, 2002-7

\begin{tabular}{|c|c|c|c|c|c|}
\hline & \multicolumn{2}{|c|}{ All firms } & \multicolumn{3}{|c|}{ Employer Firms } \\
\hline & $\begin{array}{c}\text { Sales \& } \\
\text { Receipts } \\
\text { (in 1000\$) }\end{array}$ & $\begin{array}{c}\% \text { Employer } \\
\text { Firms }\end{array}$ & $\begin{array}{c}\text { Sales \& } \\
\text { Receipts } \\
\text { (in 1000\$) }\end{array}$ & $\begin{array}{l}\text { Number of } \\
\text { Employees }\end{array}$ & $\begin{array}{c}\text { Annual } \\
\text { Payroll } \\
\text { (in 1000\$) }\end{array}$ \\
\hline & \multicolumn{5}{|c|}{ Asian-owned 2002} \\
\hline City Average & 263.0 & $26.6 \%$ & 882.3 & 6.5 & 165.7 \\
\hline \multirow[t]{2}{*}{ Suburbs Average } & 321.0 & $27.1 \%$ & 1048.0 & 6.5 & 180.2 \\
\hline & \multicolumn{5}{|c|}{ Asian-owned 2007} \\
\hline City Average & 313.7 & $23.7 \%$ & 1195.8 & 6.1 & 186.2 \\
\hline \multirow[t]{2}{*}{ Suburbs Average } & 354.8 & $24.3 \%$ & 1311.4 & 7.1 & 221.6 \\
\hline & \multicolumn{5}{|c|}{ Black-owned 2002} \\
\hline City Average & 67.0 & $7.0 \%$ & 697.8 & 8.0 & 195.7 \\
\hline \multirow[t]{2}{*}{ Suburbs Average } & 79.7 & $7.9 \%$ & 733.3 & 7.1 & 190.4 \\
\hline & \multicolumn{5}{|c|}{ Black-owned 2007} \\
\hline City Average & 66.9 & $5.5 \%$ & 857.7 & 7.2 & 199.7 \\
\hline \multirow[t]{2}{*}{ Suburbs Average } & 81.2 & $5.6 \%$ & 1060.5 & 7.6 & 198.0 \\
\hline & \multicolumn{5}{|c|}{ Hispanic-owned 2002} \\
\hline City Average & 97.6 & $9.3 \%$ & 819.0 & 9.5 & 206.6 \\
\hline \multirow[t]{2}{*}{ Suburbs Average } & 156.9 & $11.8 \%$ & 1064.1 & 7.9 & 207.7 \\
\hline & \multicolumn{5}{|c|}{ Hispanic-owned 2007} \\
\hline City Average & 122.9 & $9.3 \%$ & 1038.4 & 7.2 & 215.5 \\
\hline \multirow[t]{2}{*}{ Suburbs Average } & 154.4 & $10.7 \%$ & 1132.4 & 7.9 & 232.3 \\
\hline & \multicolumn{5}{|c|}{ Other 2002} \\
\hline City Average & 1780.2 & $30.2 \%$ & 5748.7 & 24.7 & 1149.5 \\
\hline \multirow[t]{2}{*}{ Suburbs Average } & 1286.5 & $26.1 \%$ & 4775.2 & 21.6 & 828.0 \\
\hline & \multicolumn{5}{|c|}{ Other 2007} \\
\hline City Average & 2083.5 & $27.2 \%$ & 7487.0 & 25.3 & 1468.6 \\
\hline Suburbs Average & 1510.5 & $23.9 \%$ & 6148.9 & 22.1 & 1006.1 \\
\hline
\end{tabular}

Source: Authors' calculation of Survey of Business Owners data. 
Table 5. Central City's Share of MSA Businesses and Their Economic Impact by Owner's Race/Ethnicity, 2002-7

\begin{tabular}{|c|c|c|c|c|c|}
\hline & $\begin{array}{c}\text { All } \\
\text { Firms }\end{array}$ & $\begin{array}{l}\text { Employer } \\
\text { Firms }\end{array}$ & $\begin{array}{l}\text { Total Sales } \\
\text { \& Receipts }\end{array}$ & $\begin{array}{c}\text { Total } \\
\text { Employment }\end{array}$ & $\begin{array}{c}\text { Total Annual } \\
\text { Payroll }\end{array}$ \\
\hline & \multicolumn{5}{|c|}{ Asian-owned Firms } \\
\hline 2002 & $43.50 \%$ & $46.61 \%$ & $43.67 \%$ & $45.28 \%$ & $46.23 \%$ \\
\hline 2007 & $41.47 \%$ & $43.95 \%$ & $44.80 \%$ & $42.76 \%$ & $43.72 \%$ \\
\hline \multirow[t]{2}{*}{ Change } & $-2.04 \%$ & $-2.66 \%$ & $1.13 \%$ & $-2.52 \%$ & $-2.50 \%$ \\
\hline & \multicolumn{5}{|c|}{ Black-owned Firms } \\
\hline 2002 & $54.12 \%$ & $55.01 \%$ & $54.67 \%$ & $53.87 \%$ & $54.70 \%$ \\
\hline 2007 & $52.05 \%$ & $50.48 \%$ & $50.26 \%$ & $50.22 \%$ & $51.12 \%$ \\
\hline \multirow[t]{2}{*}{ Change } & $-2.07 \%$ & $-4.53 \%$ & $-4.42 \%$ & $-3.65 \%$ & $-3.58 \%$ \\
\hline & \multicolumn{5}{|c|}{ Hispanic-owned Firms } \\
\hline 2002 & $43.85 \%$ & $44.65 \%$ & $43.26 \%$ & $47.02 \%$ & $46.12 \%$ \\
\hline 2007 & $41.90 \%$ & $42.45 \%$ & $42.02 \%$ & $42.13 \%$ & $42.54 \%$ \\
\hline \multirow[t]{2}{*}{ Change } & $-1.94 \%$ & $-2.19 \%$ & $-1.24 \%$ & $-4.89 \%$ & $-3.58 \%$ \\
\hline & \multicolumn{5}{|c|}{ Other Firms } \\
\hline 2002 & $34.10 \%$ & $39.68 \%$ & $44.84 \%$ & $44.35 \%$ & $47.61 \%$ \\
\hline 2007 & $33.05 \%$ & $38.24 \%$ & $44.13 \%$ & $43.28 \%$ & $46.93 \%$ \\
\hline Change & $-1.05 \%$ & $-1.44 \%$ & $-0.71 \%$ & $-1.07 \%$ & $-0.68 \%$ \\
\hline
\end{tabular}

Source: Authors' calculation of Survey of Business Owners data. 
Table 6. Central City' Share of MSA businesses by Owner's Race/Ethnicity, by Region, 2002-7

\begin{tabular}{|c|c|c|c|c|c|c|c|c|c|}
\hline & \multicolumn{2}{|c|}{ Asian-owned } & \multicolumn{2}{|c|}{ Black-owned } & \multicolumn{2}{|c|}{ Hispanic-owned } & \multicolumn{2}{|c|}{ Other } \\
\hline & & $\begin{array}{c}\text { All } \\
\text { Firms }\end{array}$ & $\begin{array}{c}\text { Employer } \\
\text { Firms }\end{array}$ & $\begin{array}{c}\text { All } \\
\text { Firms }\end{array}$ & $\begin{array}{c}\text { Employer } \\
\text { Firms }\end{array}$ & $\begin{array}{c}\text { All } \\
\text { Firms }\end{array}$ & $\begin{array}{c}\text { Employer } \\
\text { Firms }\end{array}$ & $\begin{array}{c}\text { All } \\
\text { Firms }\end{array}$ & $\begin{array}{c}\text { Employer } \\
\text { Firms }\end{array}$ \\
\hline \multirow{3}{*}{ Northeast } & 2002 & $59.2 \%$ & $51.4 \%$ & $65.3 \%$ & $51.8 \%$ & $61.9 \%$ & $46.1 \%$ & $29.7 \%$ & $31.9 \%$ \\
\hline & 2007 & $60.0 \%$ & $51.7 \%$ & $64.2 \%$ & $57.8 \%$ & $56.8 \%$ & $46.6 \%$ & $31.9 \%$ & $31.5 \%$ \\
\hline & Change & $0.8 \%$ & $0.3 \%$ & $-1.1 \%$ & $6.0 \%$ & $-5.1 \%$ & $0.5 \%$ & $2.2 \%$ & $-0.4 \%$ \\
\hline \multirow{3}{*}{ South } & 2002 & $23.9 \%$ & $31.8 \%$ & $33.0 \%$ & $40.0 \%$ & $32.4 \%$ & $40.6 \%$ & $27.2 \%$ & $33.6 \%$ \\
\hline & 2007 & $21.8 \%$ & $27.7 \%$ & $29.1 \%$ & $33.3 \%$ & $29.2 \%$ & $34.6 \%$ & $23.9 \%$ & $31.7 \%$ \\
\hline & Change & $-2.0 \%$ & $-4.1 \%$ & $-3.9 \%$ & $-6.7 \%$ & $-3.3 \%$ & $-6.1 \%$ & $-3.4 \%$ & $-1.9 \%$ \\
\hline \multirow{3}{*}{ Midwest } & 2002 & $13.4 \%$ & $20.4 \%$ & $66.0 \%$ & $58.9 \%$ & $28.1 \%$ & $30.7 \%$ & $9.3 \%$ & $13.7 \%$ \\
\hline & 2007 & $13.3 \%$ & $17.3 \%$ & $64.4 \%$ & $59.1 \%$ & $31.8 \%$ & $31.1 \%$ & $9.5 \%$ & $13.1 \%$ \\
\hline & Change & $-0.1 \%$ & $-3.1 \%$ & $-1.5 \%$ & $0.3 \%$ & $3.7 \%$ & $0.4 \%$ & $0.1 \%$ & $-0.6 \%$ \\
\hline \multirow{3}{*}{ West } & 2002 & $29.6 \%$ & $32.9 \%$ & $41.0 \%$ & $43.0 \%$ & $38.2 \%$ & $35.8 \%$ & $35.0 \%$ & $37.2 \%$ \\
\hline & 2007 & $29.6 \%$ & $32.8 \%$ & $38.2 \%$ & $41.2 \%$ & $35.7 \%$ & $34.4 \%$ & $51.5 \%$ & $37.0 \%$ \\
\hline & Change & $0.0 \%$ & $-0.1 \%$ & $-2.8 \%$ & $-1.8 \%$ & $-2.5 \%$ & $-1.5 \%$ & $16.5 \%$ & $-0.2 \%$ \\
\hline
\end{tabular}


Figure 1. Change in Central City Share of Minority and Total Population v.s. Change in Central City Share of Minority and Total Businesses
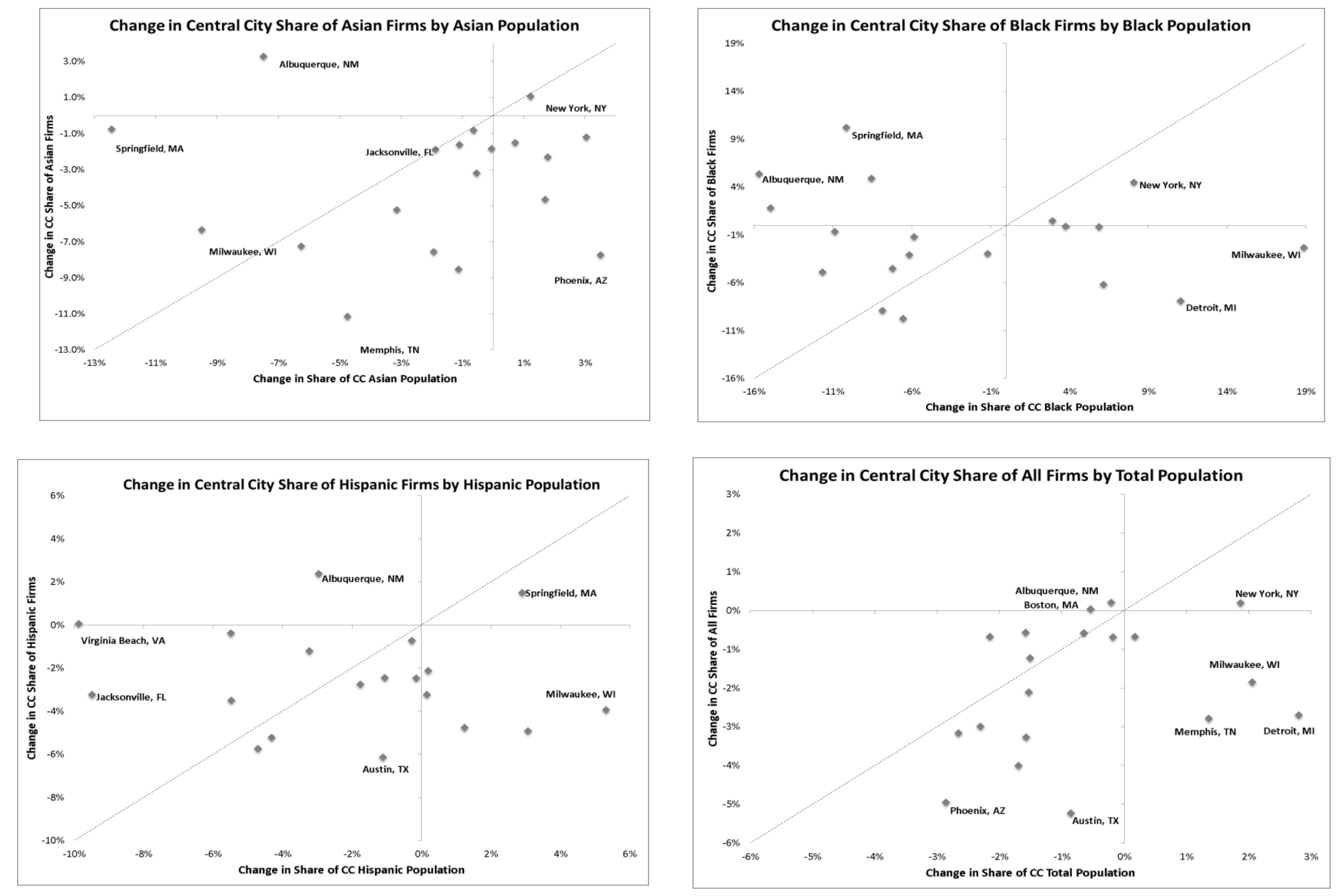
Table 7. Central City' Share of MSA businesses by Owner's Race/Ethnicity, by immigrant size and growth, 2002-7

\begin{tabular}{|c|c|c|c|c|c|c|c|c|c|}
\hline & & $\begin{array}{c}\text { All } \\
\text { Firms }\end{array}$ & $\begin{array}{c}\text { Employer } \\
\text { Firms }\end{array}$ & $\begin{array}{c}\text { All } \\
\text { Firms }\end{array}$ & $\begin{array}{l}\text { Employer } \\
\text { Firms }\end{array}$ & $\begin{array}{c}\text { All } \\
\text { Firms }\end{array}$ & $\begin{array}{c}\text { Employer } \\
\text { Firms }\end{array}$ & $\begin{array}{l}\text { All } \\
\text { Firms }\end{array}$ & $\begin{array}{l}\text { Employer } \\
\text { Firms }\end{array}$ \\
\hline & & Asian- & owned & Black- & owned & Hispanic & c-owned & Otl & \\
\hline Group 1 & 2002 & $21.7 \%$ & $28.7 \%$ & $23.0 \%$ & $32.5 \%$ & $33.4 \%$ & $39.3 \%$ & $26.2 \%$ & $31.1 \%$ \\
\hline & 2007 & $20.4 \%$ & $24.8 \%$ & $20.2 \%$ & $25.4 \%$ & $29.9 \%$ & $35.2 \%$ & $23.9 \%$ & $28.7 \%$ \\
\hline & Change & $-1.30 \%$ & $-3.92 \%$ & $-2.80 \%$ & $-7.15 \%$ & $-3.52 \%$ & $-4.09 \%$ & $-2.30 \%$ & $-2.36 \%$ \\
\hline Group 2 & 2002 & $15.0 \%$ & $21.8 \%$ & $65.9 \%$ & $58.8 \%$ & $30.8 \%$ & $31.8 \%$ & $18.8 \%$ & $16.9 \%$ \\
\hline & 2007 & $14.2 \%$ & $17.5 \%$ & $64.3 \%$ & $58.5 \%$ & $34.7 \%$ & $34.3 \%$ & $22.2 \%$ & $16.2 \%$ \\
\hline & Change & $-0.80 \%$ & $-4.23 \%$ & $-1.61 \%$ & $-0.26 \%$ & $3.95 \%$ & $2.44 \%$ & $3.49 \%$ & $-0.66 \%$ \\
\hline Group 3 & 2002 & $41.4 \%$ & $39.8 \%$ & $56.8 \%$ & $47.6 \%$ & $47.4 \%$ & $38.0 \%$ & $37.6 \%$ & $33.8 \%$ \\
\hline & 2007 & $41.8 \%$ & $40.4 \%$ & $56.9 \%$ & $52.6 \%$ & $43.4 \%$ & $37.0 \%$ & $38.1 \%$ & $34.1 \%$ \\
\hline & Change & $0.35 \%$ & $0.59 \%$ & $0.17 \%$ & $4.99 \%$ & $-3.94 \%$ & $-1.04 \%$ & $0.51 \%$ & $0.37 \%$ \\
\hline Group 4 & 2002 & $59.2 \%$ & $59.5 \%$ & $61.2 \%$ & $57.4 \%$ & $65.5 \%$ & $63.8 \%$ & $50.6 \%$ & $56.7 \%$ \\
\hline & 2007 & $58.8 \%$ & $57.6 \%$ & $58.9 \%$ & $56.1 \%$ & $60.8 \%$ & $62.5 \%$ & $49.6 \%$ & $55.0 \%$ \\
\hline & Change & $-0.40 \%$ & $-1.85 \%$ & $-2.32 \%$ & $-1.31 \%$ & $-4.67 \%$ & $-1.34 \%$ & $-1.03 \%$ & $-1.68 \%$ \\
\hline
\end{tabular}

Note: Group 1. High immigrant presence and high immigrant growth MSAs Group 2. Low immigrant presence and low immigrant growth MSAs Group 3. High immigrant presence and low immigrant growth MSAs Group 4. Low immigrant presenceand high immigrant growth MSAs 